\title{
Indonesia Islamic Banking Readiness in Facing the ASEAN Economic Community, in Terms of Islamic Banking Disclosure and Performance Indices
}

\author{
Veithzal Rivai Zainal ${ }^{1}$, Djoko Setyo Widodo ${ }^{1} \&$ Iwan Kurniawan Subagja $^{1}$ \\ ${ }^{1}$ Faculty of Economics, Universitas Krisnadwipayana Jakarta, Indonesia \\ Correspondence: Iwan Kurniawan Subagja, Faculty of Economics, Universitas Krisnadwipayana Jakarta, Po Box \\ 7774/Jat CM Jakarta Indonesia, 13077. E-mail: iwankurniawan@unkris.ac.id
}

Received: April 26, 2019; Accepted: May 12, 2019; Published: May 21, 2019

\begin{abstract}
This research is aimed to analyze the level of openness of Indonesia Islamic Banking which is viewed from Islamic Banking Disclosure Index based on Sharia Compliance Indicator, Corporate Governance Indicator and Social/Environment Indicator. This research is used the quantitative and qualitative methods. The use of a quantitative method in this research looks at the evaluation of Islamic Banking Performance Index, and the use of the qualitative method in this research looks at the evaluation of Islamic Banking Disclosure Index.

The result of research showed Islamic Banking Disclosure Index of Indonesia Islamic Banking higher than ASEAN Islamic Banking. The average of Islamic Banking Disclosure Index of Indonesia Islamic Banking has amounted $82.71 \%$, higher than ASEAN that is amounted $52.40 \%$. Based on the analysis of Islamic Banking Disclosure Index is concluded that Indonesia Islamic Banking more open to revealing the information/publication related to Sharia Compliance Indicator, Corporate Governance Indicator and Social/Environment Indicator and Islamic Banking Performance Index.
\end{abstract}

Keywords: ASEAN Economic Community, Islamic Banking Disclosure Index, Islamic Banking Performance Index, Indonesia Islamic Banking, ASEAN Islamic Banking

\section{Introduction}

ASEAN Economic Community (AEC) is the embodiment of agreement in an economic integrated model at ASEAN region, which was proclaimed at the 9th ASEAN Summit in Bali, Indonesia in 2003 (Ministry of Trade, 2007:6). If Indonesia is not able to keep the existence in AEC, it will be the loss of opportunities, especially in the economic area (Ekawati, 2014: 1). With the enactment of the AEC industry is no exception then all of the financial industry, particularly Islamic banking to compete in the AEC market.

Most people are concerned about the presence of AEC as a threat because the potential domestic market will be taken by other countries. This fear is not groundless if we will be able to demonstrate the highest competitiveness. Is Indonesia Islamic Banking ready to facing ACE? This thing is a major focus in this research.

\subsection{Research Question}

1) How is the openness level of Indonesia Islamic Banking that viewed in Islamic Banking Disclosure Index period 2012-2017?

2) How is the openness level of Indonesia Islamic Banking that viewed in Islamic Banking Performance Index period 2012-2017?

3) How is the propose of policies to a regulator, OJK and/ or BI and/ or Islamic Bank in Indonesia related to the readiness Indonesia Islamic Banking to facing AEC, particularly in terms of disclosure and performance?

\section{Literature Review}

In line with the world Islamic Banking development, the development of an index to measure/ determine the financial performance of Islamic Banking to be very important part, especially to determine how far the success level of these financial institutions to reach the target that had stated before, but it is also unless important, namely whether the Islamic financial institution complies with Islamic law (sharia compliance). 
Disclosure Index is an index that used to check/ reveal how well or clear an Islamic Financial Institution reveal information that used to stakeholders. Disclosure Index is divided into 3 (three) main indicator in valuation, namely Sharia Compliance Indicator, Corporate Governance Indicator, and Environment/ Social Indicator. Performance Index used in this research is named Islamic Banking Performance Index. Islamic Banking Performance Index is an index to evaluate the performance of the Islamic Bank of 2 (two) sides namely financial performance and Islamic performance.

To measure and/ or get the value of Islamic Banking Disclosure Index is used the checklist method of disclosure that will be researched, include Sharia Compliance, Corporate Governance, dan Social/ environmental. Meanwhile, to measure and/ or evaluate Islamic Banking Performance Index has used ratio method. The ration that will measure/ evaluate in Islamic Banking Performance Index consist of the common ratio, namely profitability indicator, asset quality indicator, efficiency indicator, liquidity indicator, and risk and solvability indicator as well as a financial ratio to look sharia compliance which is called Islamic Performance Index.

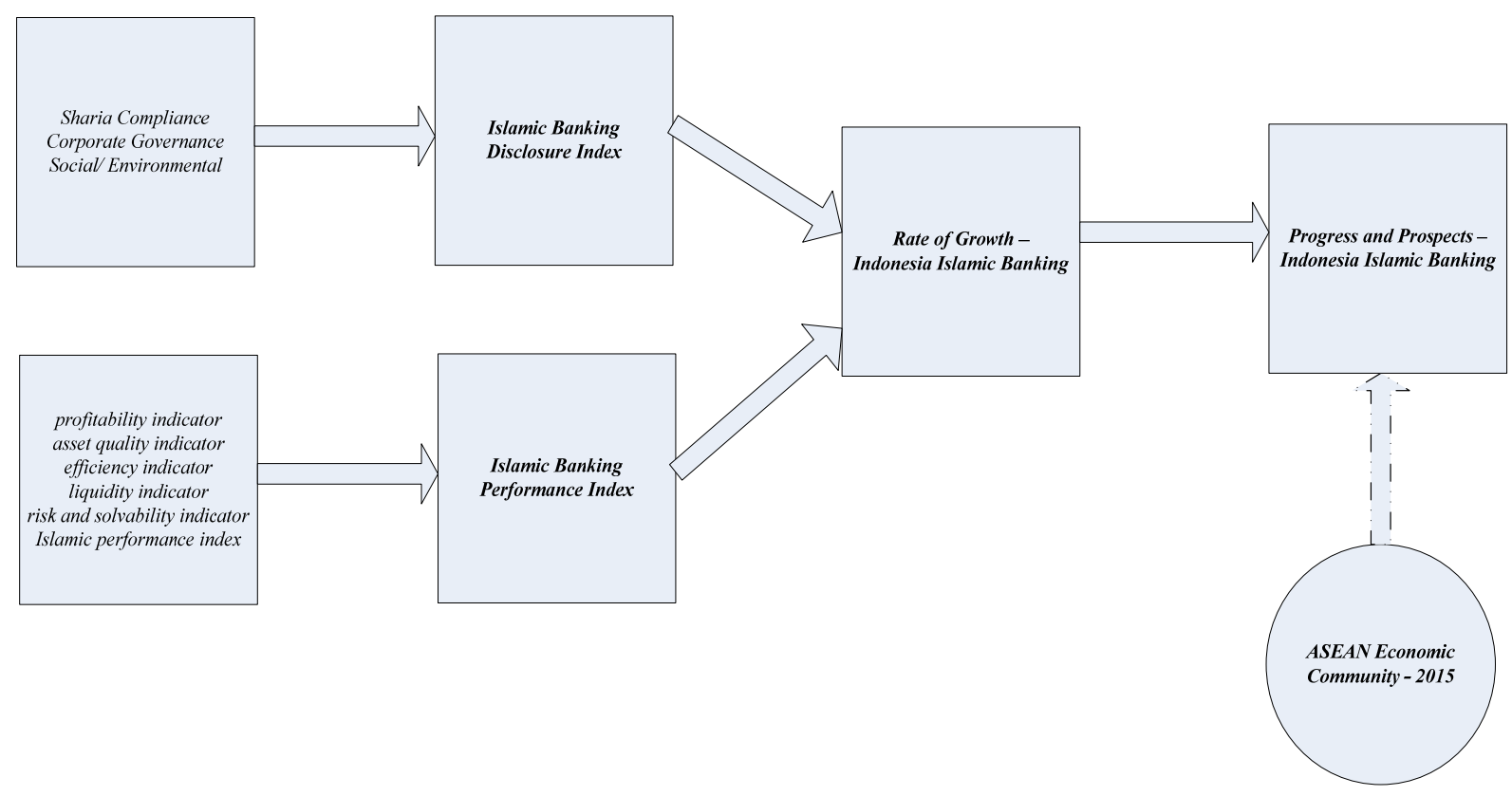

Figure 1. The framework of Readiness Analysis in Indonesia Islamic Banking in terms of Islamic Banking Disclosure and Performance Indices

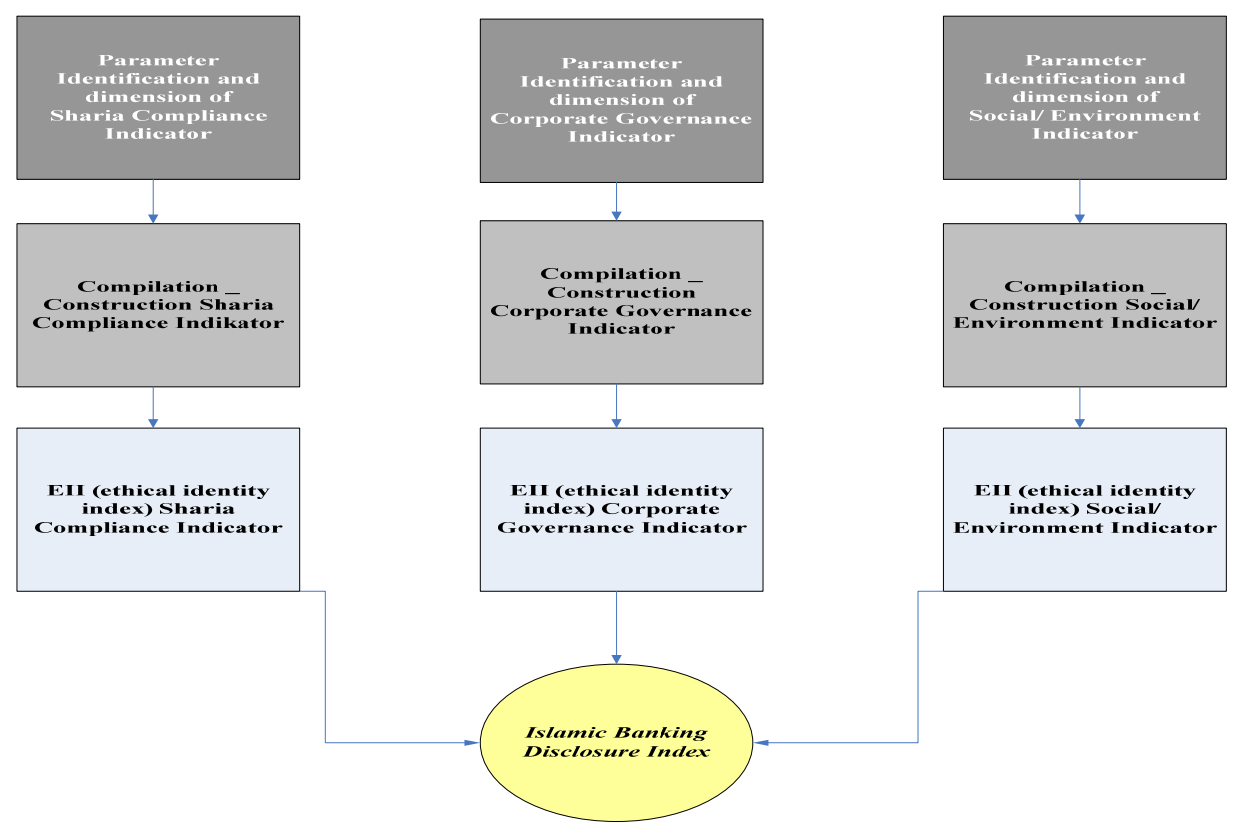

Figure 2. The Framework of Islamic Banking Disclosure Index Establishment 


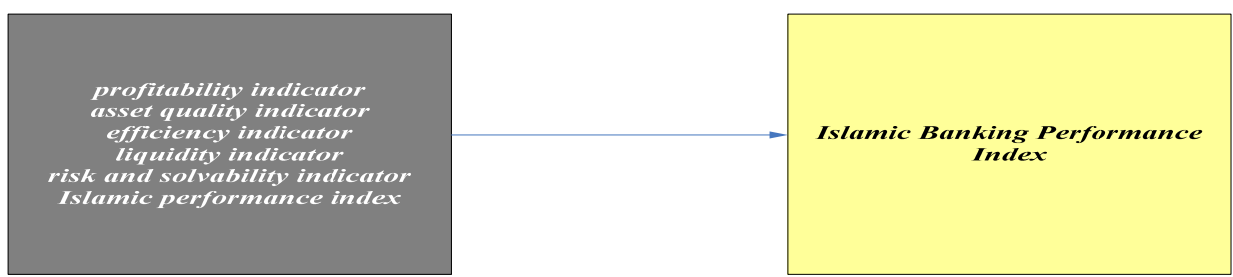

Figure 3. The Framework of Islamic Banking Performance Index Establishment

\section{Methodology}

\subsection{Research Technique}

The research technique in this research is explorative technique. This is because the researchers have conducted development to the previous research. The development is conducted include Disclosure Index and Performance Index.

\subsection{Research Instrument}

Islamic Banking Disclosure Index is the mean (average value) All of each indicator that becomes part of the establishment Islamic Banking Disclosure Index, namely sharia compliance indicator, corporate governance indicator and social/ environment indicator. By averaging the three indicators is forming the index and it will show how the projection is generally related to the disclosure in Islamic Bank that become the object of this research.

$$
\text { Islamic Banking Disclosure Index }=\frac{\sum\left[\mathrm{EII}_{j} \mathrm{SCI}+\mathrm{EII}_{j} \mathrm{CGI}+\mathrm{EII}_{j} \mathrm{SEI}\right]}{n}
$$

Where are :

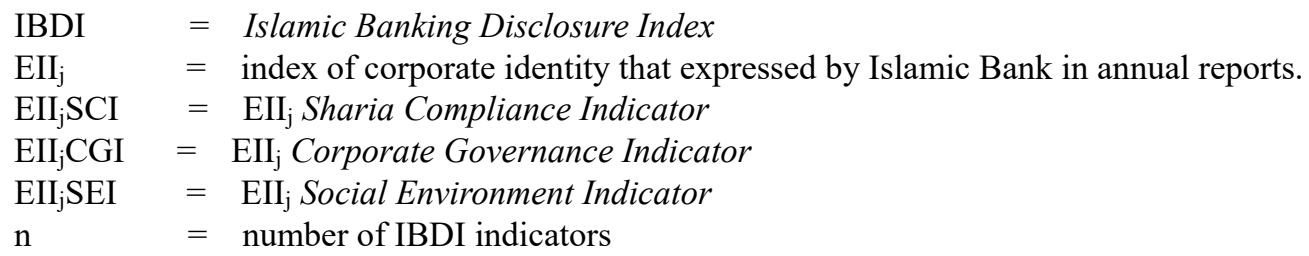

In this research, performance evaluation of Islamic Bank is evaluated in 2 (two) sides namely financial performance and Islamic performance. Compilation of these indicators is called Islamic Banking Performance Index.

\subsection{Research Object}

1) Islamic Bank which is a stand-alone corporation in all ASEAN countries.

2) Islamic Bank has published Annual Financial Statement (annual report) and Good Corporate Governance Report until 2017.

3) Islamic Bank as mentioned in point 1 and 2 has total assets in $2017 \geq$ average total asset of 3 (three) Islamic Bank in Indonesia in term of their assets.

\subsection{Data Collection Method}

The data that used in this research is secondary data from Annual Financial Statement (annual reports), Good Corporate Governance Report from each of ASEAN Islamic Bank during the research period. The research data was processed and evaluated to provide Islamic Banking Disclosure Index and Islamic Banking Performance Index.

\section{Result and Discussion}

\subsection{Islamic Banking Analysis}

Table 1. Indonesia Islamic Banking Outreach

\begin{tabular}{llll}
\hline Bank Categories & $\mathbf{2 0 1 5}$ & $\mathbf{2 0 1 6}$ & $\mathbf{2 0 1 7}$ \\
\hline Islamic Bank & 11 & 11 & 11 \\
Islamic Business Unit & 24 & 24 & 23 \\
- Total Office & 1737 & 2262 & 2526 \\
Islamic Rural Bank & 155 & 158 & 160
\end{tabular}


Source: Statistik Bank Indonesia, 2017

\begin{tabular}{llll} 
- Total Office & 364 & 401 & 399 \\
Total account (third party of funds) & 8,2 & 10,8 & 12,3 \\
Total employee & 27.660 & 31.578 & 42.062 \\
\hline
\end{tabular}

Table 2. Indonesia Islamic Banking Performance

\begin{tabular}{|c|c|c|c|c|}
\hline \multirow{2}{*}{ Financial Position } & \multicolumn{2}{|c|}{ Islamic Bank } & \multicolumn{2}{|c|}{ Islamic Business Unit } \\
\hline & 2016 & 2017 & 2016 & 2017 \\
\hline \multicolumn{5}{|l|}{ Source of Funds } \\
\hline Third Party of Funds & 117.8 & 137.0 & 29.7 & 37.0 \\
\hline Liabilities to the Bank & 10.0 & 10.5 & 1.6 & 2.1 \\
\hline \multicolumn{5}{|l|}{ Placement of Funds } \\
\hline Deferred Payment & 112.4 & 134.6 & 35.1 & 44.7 \\
\hline Placement to BI & 19.2 & 18.0 & 7.5 & 8.1 \\
\hline Placement to other Banks & 3.1 & 2.5 & 2.9 & 3.3 \\
\hline Marketable Securities & 7.0 & 8.2 & 0.8 & 1.4 \\
\hline Current Year Profit & 1.8 & 1.6 & 0.8 & 1.5 \\
\hline Total Asset & 147.6 & 171.3 & 47.4 & 58.2 \\
\hline
\end{tabular}

Source: Statistik Bank Indonesia, 2017

The development of Islamic Banking which is relatively fast that not followed with their market share, where an actual value in Islamic Banking market share in 2017 has amounted 4.58\% (Buchori, 2013:5). The value of Islamic Banking market share is the lowest than conventional banking market share which is amounted $95.42 \%$. Estimated at $5.25 \%$ to $6.25 \%$ (Siregar, 2013:12), still in the lowest composition than conventional banking market share.

Indonesia is the country with the largest population (40.6\%) and the largest land area (41.9\%). The country with the smallest population in Brunei Darussalam and the smallest land area in Singapore.

The formation of AEC is also bringing major implications for Indonesia Islamic Banking. But, unlike conventional banking, where with AEC bring the huge market to the conventional banking, for Islamic Banking which is bringing a little market share. Among the ASEAN countries, only Malaysia, Singapore, and Brunei Darussalam which has a potential market in sharia products and services. But because the population of these countries is lower, the market is very limited. Thus, opportunities for Indonesia Islamic Banking with the implementation of AEC is not too much (Directorate of Islamic Banking BI, 2012:76).

\subsection{Islamic Banking Disclosure Index}

Table 3. Rank of Islamic Banking Disclosure Index

\begin{tabular}{|c|c|c|c|c|c|c|c|c|c|c|}
\hline \multirow{2}{*}{ Country } & \multirow{2}{*}{ Islamic Bank } & \multirow{2}{*}{ Code } & \multicolumn{7}{|c|}{ Islamic Banking Disclosure Index } & \multirow{2}{*}{ Rank } \\
\hline & & & 2012 & 2013 & 2014 & 2015 & 2016 & 2017 & Mean & \\
\hline Indonesia & $\begin{array}{l}\text { PT. Bank } \\
\text { Mandiri Sharia }\end{array}$ & BSM & $84,48 \%$ & $93,14 \%$ & $94,12 \%$ & $94,12 \%$ & $94,12 \%$ & $94,12 \%$ & $92,35 \%$ & 1 \\
\hline Indonesia & $\begin{array}{l}\text { PT. Bank } \\
\text { Muamalat } \\
\text { Indonesia }\end{array}$ & BMI & $78,92 \%$ & $82,68 \%$ & $92,16 \%$ & $92,16 \%$ & $92,16 \%$ & $92,16 \%$ & $88,37 \%$ & 2 \\
\hline Indonesia & $\begin{array}{l}\text { PT. Bank BRI } \\
\text { Sharia }\end{array}$ & BRIS & & $63,89 \%$ & $78,59 \%$ & $90,36 \%$ & $90,36 \%$ & $90,36 \%$ & $82,71 \%$ & 3 \\
\hline Malaysia & $\begin{array}{l}\text { RHB Islamic } \\
\text { Bank Berhad }\end{array}$ & RHB & $61,27 \%$ & $61,27 \%$ & $61,27 \%$ & $61,27 \%$ & $61,27 \%$ & $61,27 \%$ & $61,27 \%$ & 4 \\
\hline Malaysia & $\begin{array}{l}\text { CIMB Islamic } \\
\text { Bank Berhad }\end{array}$ & CIMB & & $58,33 \%$ & $58,33 \%$ & $58,33 \%$ & $58,33 \%$ & $58,33 \%$ & $59,02 \%$ & 5 \\
\hline Malaysia & $\begin{array}{l}\text { Affin Islamic } \\
\text { Bank Berhad }\end{array}$ & $\mathrm{AFF}$ & $55,39 \%$ & $57,35 \%$ & $57,35 \%$ & $57,35 \%$ & $57,35 \%$ & $57,35 \%$ & $57,02 \%$ & 6 \\
\hline
\end{tabular}


1) Based on the above table, it is known Indonesia Islamic Banking rank relatively higher than ASEAN Islamic Banking. Where Indonesia Islamic Banking was ranked the best position than the others Islamic Bank in ASEAN.

2) The ranking of Islamic Banking Disclosure Index which projected in Table 3 is indicating during period 20122017, Indonesia Islamic Banking is more open and more complete in the reveal of disclosure that is required in the formation of Islamic Banking Disclosure Index which consists of Sharia Compliance, Corporate Governance, and social / Environment Indicator.

3) The fulfillment of disclosure is relatively affecting the formation of public trust. The implications of public trust are expected in line with the increasing of sharia market share.

4) Based on the research that has been done before, it is known that the right and accordance disclosure to the principles of Islamic law will affect the market share and/ or the level of public trust to Islamic Bank. As the result of research that was conducted by Ariani (2007:58) in thesis research which titled "Public Perception to Islamic Bank in Medan", which is stated services and professionalism of Islamic Bank (sharia compliance) only brought influence $23.3 \%$ to respondents perception to Islamic Bank in Medan. This is certainly indicated the level of public trust in Islamic Bank that has an important function.

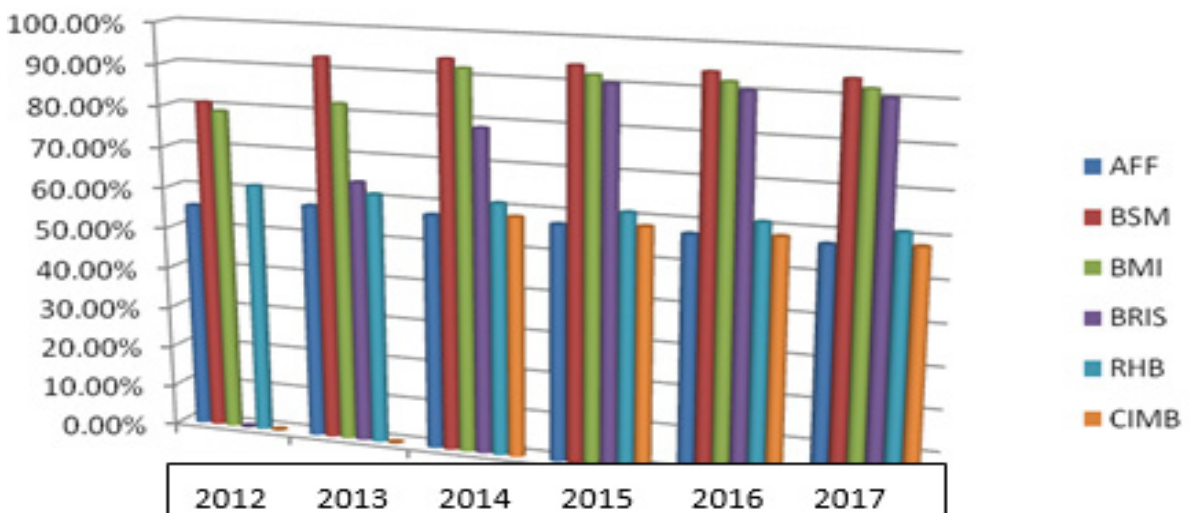

Figure 4. Comparison between Islamic Banking Disclosure Index in Indonesia and ASEAN

Based on Fig. 4, it could be seen clearly that Indonesia Islamic Banking has higher Islamic Banking Disclosure Index than ASEAN Islamic Banking. The average value of Islamic Banking Disclosure Index of Indonesia Islamic Banking during 2012-2017 has amounted 82.71\%, which is higher than Islamic Banking Disclosure Index of ASEAN Islamic Banking that amounted 52.40\%.

\subsection{Islamic Banking Performance Index}

Islamic Banking Performance Index is formed by several indicators that have different on their valuation, so the valuation of Islamic Banking Performance Index is not accumulated.

1) Profitability Indicator

Performance of Indonesia Islamic Banking is relatively good enough in profitability indicator. This is showed at ROA and ROE which are relatively high, where BSM is ranked top 3 for both indicators. However, Price Earning Ratio (PER) of Indonesia Islamic Banking is relatively lower than ASEAN Islamic Banking. This is triggered higher in Operational Expenses to Operational Incomes at Indonesia Islamic Banking $(>70 \%)$.

2) Asset quality indicator

Based on this indicator, asset quality in Indonesia Islamic Banking is relatively not good enough compared than the other ASEAN Islamic Banking. There are not Indonesia Islamic Banking that has in the top 3 best asset quality. This is also because relatively small of a total asset in Islamic Bank in Indonesia.

\section{3) Efficiency indicator}

The level of efficiency and performance of the Islamic Bank in Indonesia is relatively good. Where BSM is in top 3 (three). However, the implementation activities in the Islamic Bank in Indonesia is not good enough than the others Bank in ASEAN. This is most likely triggered that still relatively higher in operational expenses in Indonesia than ASEAN.

4) Liquidity Indicator 
From the liquidity indicator, Indonesia Islamic Banking is relatively good, where the Indonesia Islamic Banking is in top 4 (four) biggest in liquidity valuation. Where the Islamic Bank has relatively good ability to cover their short-term liabilities, especially if there are liquidity problems that might occur.

\section{5) Risk and solvability indicator}

In the assessment of this indicator, there are no Islamic banks in Indonesia who are in position three (3) large. That is, the ability of Islamic banks in Indonesia is still relatively low compared to other ASEAN banks to repay the entire debt that is using all its assets if insolvent. It is considered appropriate that Islamic banking assets in other ASEAN larger and more developed than the Islamic banking in Indonesia in general.

6) Islamic performance indicator

Based on the valuation of Islamic Performance indicator, Islamic Bank in Indonesia is relatively good. Where 3 (three) Islamic Banks in Indonesia that become research object is the Bank who had given proportional intensity to sharia compliance. This is most likely due to fairly strict Sharia compliance which regulated in Indonesia compared than ASEAN countries. And for sure, this is become one positive point to running Indonesia Islamic Banking.

\subsection{Policies Analysis in Facing AEC}

On step has been carried out by Malaysia in facing the competition in the banking sector at AEC was merged 3 (three) banks, namely CIMB Group, RHB Capital and Malaysia Building Society. This merger process has added 1 (one) the largest bank in Southeast Asia with potential total asset amounted Rp. 2,300 trillion (US\$ 24 billion). Currently, the Bank in Indonesia that has the biggest total asset is PT. Bank Central Asia Tbk. (BCA), with the range value of their total asset amounted US\$ 24 billion (Gunadi, 2014). If compared with the biggest Indonesia Islamic Bank in a total asset which is Bank Mandiri Sharia with total asset US\$ 5.3 billion, assets of Islamic Bank in Indonesia is too small than a conventional bank in Indonesia.

Answering this challenge, Deputy Governor of Bank Indonesia, Halim Alamsyah said the establishment of Islamic state bank stand-alone as a strategic step, in line with the liberalization of the banking sector in the implementation of AEC. The most realistic way is to merge 4 (four) Islamic Banks state-owned namely Bank Mandiri Sharia (BSM), Bank Rakyat Indonesia Sharia (BRIS), Bank Negara Indonesia Sharia (BNI Sharia) and Sharia Business Unit Bank Tabungan Negara (BTN-Sharia) (Fatkhul, 2013).

Indupurnahayu (2007) said in a research paper entitled "Banking Merger Implementation in Indonesia, Could be done the Stability and Efficiency? Some of the benefits of bank mergers, among others:

1) To make the strengthening of capital structure. If two or more inter-bank merger, it will increase they are strengthening of capital structure which reflected in the capital adequacy ratio (CAR) improvement.

2) With the strong capital structure, the competitiveness of post-merger bank will be increased so it will make better positioning of this bank.

3) The post-merger bank will be able to expand their market segmentation that followed by expansion of the type and variety of products and banking services.

4) The merger of national banks indirectly could avoid the capital increase, thus preclude the opportunities to foreign investors and control of national banks by foreign capital.

5) From the government side, it would receive more income from taxes and dividends as well as cash, when the post-merger bank divested.

Based on the above presentation, the idea to implement the merger of Islamic Bank that state-owned is relevant to conduct immediately, also based on the financial condition of these banks which is evaluated really good. This idea of accordance with the research of Putra (2013:16) which entitled "By looking at the financial ratios of the merge conventional bank, would this activity succeed?", it is compared financial condition of Bank Mandiri (merged in 1999), Bank Danamon (merged in 2000), and Bank Permata (merged in 2002), by taking 1 year time before and after the merger process and financial crisis in 2008, the result of research are among others:

1) Based on the percentage of financial ratios (liquidity ratio, solvability ratio, and profitability ratio) of Bank is known relatively smaller than before the merger.

2) Based on the percentage of financial ratios (liquidity ratio, solvability ratio, and profitability ratio) of Bank is known to survive well from the financial crisis 2008.

3) The merger process was conducted to Bank Mandiri (in 1999), Bank Danamon (in 2000), and Bank Permata (in 2002) which gave the significant changes to an improvement of banks financial performances. 


\section{Conclusion and Recommendation}

\subsection{Conclusion}

a) Indonesia Islamic Banking has Islamic Banking Disclosure Index higher than Islamic Disclosure Index in ASEAN Islamic Banking.

b) The average of Islamic Banking Disclosure Index in 2012-2017 has amounted $82.71 \%$ higher than Islamic Banking Disclosure Index in ASEAN Islamic Banking that is amounted 52.40\%.

c) Annual report of each Islamic Bank in Indonesia is relatively more fully in the reveal disclosure that required in the formation of Islamic Banking Disclosure Index.

d) Based on analyze of Islamic Disclosure Index that is concluded Indonesia Islamic Banking more transparency to reveal the information/ publicity related on Sharia Compliance Indicator, Corporate Governance Indicator and Social/ Environment Indicator.

e) Indonesia Islamic Banking has the average value of Islamic Banking Performance Index relative not too much different to ASEAN Islamic Banking.

f) Based on analyze of Islamic Banking Performance Index that is concluded Indonesia Islamic Banking have better financial performance and more stable, with the analyze value which is no more different to ASEAN Islamic Banking.

g) Based on analyzing Islamic Banking Disclosure and Performance Indices, that are concluded Indonesia Islamic Banking ready to facing the regional competition to ASEAN Islamic Banking on AEC.

h) The merger to establish the Islamic Banking state-owned is need to implement immediately because this will increase significantly the quality of performance of Islamic Bank in Indonesia, and expected to survive the regional and/ or global competition.

\subsection{Recommendation}

\subsubsection{Recommendation to Indonesia Islamic Banking}

a) There are need more encouragement and improvement to increase the Islamic Banking market share. But, this needs more time to adapt corporate culture, IT system, human resources, and others of 4 (four) banks.

b) Besides the government, there are also need the contribution of shareholders to accelerate the consolidation process/ merger. Because this will improve directly the efficiency of the Bank's operational activities and productivities.

c) It is going to do to make Indonesia Islamic Banking survive in AEC.

5.2.2 Recommendation to the Further Research

a) It is recommended to conduct further research after implementing of AEC. The further research should be done on all Islamic Banking in ASEAN.

b) For the further research, it is needed to add more variable (except disclosure and performance) in order to analyze the readiness of Indonesia Islamic Banking to facing AEC.

c) When the merger has been carried out, further research to determine changes in the financial ratios of Islamic banks and/or conventional banks are converted into Islamic banks are advised to do.

\section{Acknowledgments}

Author, declare there is no conflict of interest.

\section{References}

Ariani, D. (2007). Persepsi Masyarakat Umum Terhadap Bank Syariah di Medan. Thesis, Universitas Sumatera Utara.

Bank Indonesia. (2011). Tanya Jawab Peraturan Bank Indonesia Nomor 13/2/PBI/2011 Tentang Pelaksanaan Fungsi Kepatuhan Bank Umum, Tanggal 12 Januari 2011.

Bank Indonesia. (2009) Frequently Asked Question Peraturan Bank Indonesia Nomor 11/33/PBI/2009 Tentang Pelaksanaan Good Corporate Governance Bagi Bank Umum Syariah dan Unit Usaha Syariah. Tanggal 7 Desember 2009.

Buchori, A. (2013). BI: Market Share Bank Syariah sudah 5\%. Retrieved from http://www.infobanknews.com/2013/11/bi-market-share-bank-syariah-sudah-5/ 
Departemen Perdagangan Republik Indonesia. (2007). Menuju ASEAN Economic Community 2015.

Direktorat Perbankan Syariah Bank Indonesia. (2012). Kajian Model Bisnis Perbankan Syariah. Departemen Perbankan Syariah Bank Indonesia.

Ekawati, R. (2014). Kontribusi Total Quality Management dan Human Capital Terhadap Inovasi dan Mass Customization serta Dampaknya Terhadap Kinerja Perusahaan (Survei pada UKM Garmen di Jawa Barat. Unpublished doctoral dissertation, Fakultas Ekonomi dan Bisnis, Universitas Padjadjaran.

Fatkhul, M. (2013). Konsolidasi Bank Syariah Merupakan Strategi Realistis. Retrieved from http://www.bisnis.com/m/bank-indonesia-konsolidasi-bank-syariah-merupakan-strategi-realistis

Gunadi, B. (2014). Ini Tanggapan Bos Bank Mandiri Soal Merger 3 Bank Malaysia. Retrieved from http://bisnis.liputan6.com/read/2083742/ini-tanggapan-bos-bank-mandiri-soal-merger-3-bank-malaysia

Indupurnahayu. (2007). Implementasi Merger Perbankan di Indonesia, Dapatkah Stabilitias dan Keefisienan Tercapai? Journal Economic, ISSN 2086-7840, pp. 36-56.

Rivai, V., \& Arifin, A. (2010). Islamic Banking - Sistem Bank Islam Bukan Hanya Solusi Menghadapi Krisis Namun Solusi dalam Menghadapi Berbagai Persoalan Perbankan \& Ekonomi Global. Jakarta : Bumi Aksara.

Siregar, Mulia. (2013, 16 Desember). Outlook Perbankan Syariah 2014. Dipersentasikan pada Seminar Akhir Tahun Perbankan Syariah 2013 - Bank Indonesia, Jakarta.

Putra, Y. B. (2013). Dengan melihat rasio keuangan bank konvensional hasil merger, mungkinkah merger bank syariah akan berhasil? Forum Riset Perbankan Syariah VI.

Bank Indonesia. (2009). Peraturan Bank Indonesia Nomor 11/33/PBI/2009 (2009). Tentang Pelaksanaan Good Corporate Governance Bagi Bank Umum Syariah dan Unit Usaha Syariah. Tanggal 7 Desember 2009.

Bank Indonesia. (2011). Peraturan Bank Indonesia Nomor 13/2/PBI/2011 Tentang Pelaksanaan Fungsi Kepatuhan Bank Umum, Tanggal 12 Januari 2011.

\section{Copyrights}

Copyright for this article is retained by the author(s), with first publication rights granted to the journal.

This is an open-access article distributed under the terms and conditions of the Creative Commons Attribution license (http://creativecommons.org/licenses/by/4.0/). 